\title{
Propachyrucos robustus Roth, 1899 (Notoungulata, Hegetotheriidae) wrongly synonymized with Hemihegetotherium cf. H. Tantillum Vera, 2019
}

Para citar este artículo: Federico D. Seoane and Esperanza Cerdeño (2020). Propachyrucos robustus Roth,1899 (Notoungulata, Hegetotheriidae) wrongly synonymized with Hemihegetotherium cf. H. tantillum Vera, 2019. Publicación Electrónica de la Asociación Paleontológica Argentina 20 (1): 29-30.

Link a este artículo: http://dx.doi.org/10.5710/PEAPA.10.05.2020.316

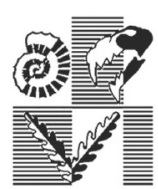

ISSN 2469-0228

\section{Asociación Paleontológica Argentina}

Maipú $6451^{\circ}$ piso, C1006ACG, Buenos Aires

República Argentina

Tel/Fax (54-11) 4326-7563

Web: www.apaleontologica.org.ar 


\title{
PROPACHYRUCOS ROBUSTUS ROTH, 1899 (NOTOUNGULATA, HEGETOTHERIIDAE) WRONGLY SYNONYMIZED WITH HEMIHEGETOTHERIUM CF. H. TANTILLUM VERA, 2019
}

\author{
FEDERICO D. SEOANE¹ AND ESPERANZA CERDEÑO²
}

1Universidad de Buenos Aires, CONICET, Instituto de Estudios Andinos Don Pablo Groeber (IDEAN), Departamento de Geología, Facultad de Ciencias Exactas y Naturales. Ricardo Güiraldes 2160, C1428EGA Buenos Aires, Argentina.seoanef@gl.fcen.uba.ar

2Paleobiología y Paleoecología, Instituto de Nivología, Glaciología y Ciencias Ambientales (IANIGLA); Centro Científico Tecnológico-CONICET-Mendoza. Avda. Ruiz Leal s/n, M5500 Mendoza, Argentina.espe@mendoza-conicet.gob.ar

Roth (1899) described the new species Propachyrucos depressus, P. medianus, and P. robustus (Notoungulata, Hegetotheriidae) from the Collón Curá Formation (middle Miocene), Province of Neuquén, Argentina. They were later transferred to Pachyrukhos Ameghino, 1885, by Pascual et al. (1978) without any systematic discussion, likely based on the stratigraphic provenance of Pachyrukhos (see Seoane and Cerdeño, 2019; Seoane et al., 2019; Vera, 2019). Mones (1986) listed these species as belonging to Propachyrucos, but posterior authors followed Pascual et al.'s proposal (Kramarz et al., 2011; López et al., 2018). The recent systematic revision by Seoane and Cerdeño (2019) justified that Propachyrucos depressus and P. medianus belong to Pachyrukhos. However, they considered both species as nomina dubia, because their p2 is not known and this tooth would allow assigning them to one of the two valid species: Pachyrukhos moyani Ameghino, 1885, and Pa. politus (Ameghino, 1902); Pa. robustus was not discussed by Seoane and Cerdeño (2019).

Vera (2019) revised Propachyrucos robustus (wrongly spelled Propachyrukhos in that paper) and, simultaneously, defined the species Hemihegetotherium tantillum Vera, 2019, based on specimens from the Collón Curá Formation. She revised the holotype of $P$. robustus, MLP 12-3161, and proposed the synonymy of this species name with Hemihegetotherium cf. H. tantillum sp. nov. Vera (2019) explained that MLP 12-3161 is close to Hemihegetotherium, but the incompleteness of its $\mathrm{m} 3$ prevented its identification at species level. Based on its similar size to H. tantillum, Vera proposed the mentioned synonymy, which we consider a confusing and erroneous nomenclatural act. First, the synonymy of a species name with a taxon in open nomenclature is not endorsed by the ICZN (1999). Second, if the author had proposed the synonymy between $P$. robustus and $H$. tantillum, the former would have priority of name, as Vera (2019) recognized, but she explained that the new name would avoid a possible case of secondary homonymy with "Hemihegetotherium robustum" Rovereto, 1914. But, in this case, $H$. tantillum would not be a new species but a nomen novum (ICZN, 1999, glossary).

Seoane and Cerdeño (2019) also revised the specimen MLP 12-3161, stating that features described in H. tantillum, such as similar length of trigonid and talonid, convex distal face, and projections of mesial and distal ends, are not present in $P$. robustus. Conversely, they highlighted several features shared by MLP 12-3161 and Hegetotherium mirabile Ameghino, 1887, like trigonid shorter than talonid, straight distal face, and the morphology of lobes, but the absence of posterolingual projection precluded the proposal of synonymy between $P$. robustus and Hegetotherium mirabile. Consequently, Seoane and Cerdeño (2019) considered Propachyrucos robustus as nomen dubium, nomenclatural act that we confirm herein. 


\section{ACKNOWLEDGMENTS}

The authors thank the editor and reviewers for their useful comments. This is an R-351 FDS's contribution to the IDEAN.

\section{REFERENCES}

Ameghino, F. 1885. Première contribution à la conaissance de la faune mammalogique des couches à Pyrotherium. Boletín del Instituto Geográfico Argentino 15: 603-660.

Ameghino, F. 1887. Enumeración sistemática de las especies de mamíferos fósiles coleccionados por Carlos Ameghino en los terrenos eocenos de Patagonia austral y depositados en el Museo La Plata. Boletín del Museo de La Plata 1: 1-26.

Ameghino, F. 1902. Première contribution à la conaissance de la fauna mammalogique des couches à Colpodon. Boletín de la Academia Nacional de Ciencias de Córdoba 17: 71-141.

ICZN, 1999. International Code of Zoological Nomenclature. International Commission on Zoological Nomenclature. https://www.iczn.org/thecode/the-international-code-of-zoological-nomenclature/thecode-online/

Kramarz, A.G., Forasiepi, A.M., and Bond, M. 2011. Vertebrados cenozoicos. $18^{\circ}$ Congreso Geológico Argentino (Neuquén), Actas: 557574.

López, G., Bond, M., and Pérez, M.E. 2018. Pachyrukhinae (Mammalia, Notoungulata, Hegetotheriidae) from the early-middle Miocene of Patagonia, Argentina. $6^{\circ}$ Congreso Latinoamericano de Paleontología de Vertebrados (Villa de Leyva), Resúmenes: 48-49.

Mones, A. 1986. Paleovertebrata Sudamericana. Catálogo Sistemático de los Vertebrados Fósiles de América del Sur, Parte I. Lista Preliminar y Bibliografía. Courier Forschungsinstitut Senckenberg, 82: 1-625.

Pascual, R., Bondesio, P., Scillato-Yané, G.J., Vucetich, M.G., and Gasparini, Z 1978. Vertebrados. $7^{\circ}$ Congreso Geológico Argentino (Neuquén), 177-184.
Rovereto, C. 1914. Los estratos araucanos y sus fósiles. Anales del Museo Nacional de Historia Natural de Buenos Aires 25: 1-247.

Roth, S. 1899. Apuntes sobre la geología y la paleontología de los territorios de Río Negro y Neuquén (diciembre de 1895 á junio de 1896). Revista del Museo de La Plata 9: 141-197.

Seoane, F.D. and Cerdeño, E. 2019. Systematic revision of Hegetotherium and Pachyrukhos (Hegetotheriidae, Notoungulata) and a new phylogenetic analysis of Hegetotheriidae. Journal of Systematic Palaeontolology 17: 1415-1443.

Seoane, F.D., Cerdeño, E., and Singleton, H. 2019. Re-assessment of the Oligocene genera Prosotherium and Propachyrucos (Hegetotheriidae, Notoungulata). Comptes Rendus Palevol 18: 643662.

Vera, B. 2019. A new species and the record of Hemihegetotherium (Notoungulata, Hegetotheriidae) in the middle to late Miocene of Patagonia, Argentina. Journal of South American Earth Science 93: 23-35.

Editorial Note: Both this work and the nomenclatural acts it contains have been registered in the ZooBank. The work is permanently archived in the Internet Archive.

LSID urn:Isid:zoobank.org:pub:600AB6E2-7996-4963-9354-AB080E1E72F5

doi: 10.5710/PEAPA.10.05.2020.316

Recibido: 21 de marzo 2020

Aceptado: 10 de mayo 2020 